\title{
Transformational Government: Governance, Organization, and Management Minitrack Introduction
}

\author{
Miriam Lips \\ Victoria University of \\ Wellington, New Zealand \\ miriam.lips@vuw.ac.nz
}

\author{
Leif Skiftenes Flak \\ University of Agder, Norway \\ leif.flak@uia.no
}

\author{
J. Ramon Gil-Garcia University \\ at Albany, State University of \\ New York Email: \\ jgil-garcia@ctg.albany.edu
}

Research demonstrates the critical importance of treating e-Government as a multidisciplinary and multidimensional phenomenon in order to understand and explain its potential for ICT-enabled government transformation. More specifically, strategic, political, institutional, managerial, organizational, legal, economic, and external relationship factors have been identified as key aspects in the study of e-government and, particularly, transformational government.

This minitrack examines the complexity of effectively governing, organizing, and managing e-Government and its transformational potential. Increasingly, this involves inter-organizational collaboration and cocreation of value, multi-sector and cross-jurisdictional networks, and the management of a large variety of relationships with both internal and external stakeholders. Moreover, many governments in developing countries perceive ICT-enabled government transformation as an opportunity to establish 'good governance' in their countries, which involves improved accountability and transparency as well as fighting corruption.

This minitrack welcomes papers that focus on the transformational aspects of e-Government as well as their implications for government and society. It invites empirical, theoretical, and/or conceptual contributions that show the importance of governmental, institutional, organizational, managerial, and democratic aspects of transformational eGovernment.

Research topics include, but are not limited to:

- $\quad$ Strategies and value foundations for ICT-enabled government

- $\quad$ Strategies for the design, development, implementation, maintenance, performance, and evaluation of e-Government applications

- Governance, accountability, and transparency

- Theoretical premises and development for transformational government
- $\quad$ Service transformation and multi-channel service delivery

- Integration of government data, services, and/or processes

- User-centric e-Government and e-Government uptake

- Mobile e-Government

- Transformational aspects and implications of data analytics, policy informatics, and smart cities

- Change management in e-Government initiatives

- Transformational aspects of e-engagement and eparticipation initiatives

- $\quad$ E-Government business models and benefits realization from e-Government initiatives

- Efficiency and/or effectiveness through eGovernment initiatives

- Co-creation of public value through interorganizational collaboration, public- private partnerships, and other collaborative arrangements in the public sector and between government agencies and external stakeholders (e.g. citizens, businesses, NGOs)

- Stakeholder engagement in e-Government initiatives

- Cross-government information sharing, regional, national and transnational information- sharing networks, information integration, privacy, and security

- Impact, outcomes, and implications of eGovernment initiatives

- Methods and frameworks for e-Government evaluation and performance assessment

- Innovation management, benchmarking, and trend monitoring in e-Government

- $\quad$ EAM - e-Government Architecture Management

- IT/IS Planning and Management in Government

- Political, economic, legal, and social aspects of eGovernment

- Organizational and managerial aspects of eGovernment 